\title{
Notes on determinations of nitrate in plant material
}

\author{
I. Novozamsky, V. J. G. Houba, D. van der Eijk and R. van Eck \\ Department of Soil Science and Plant Nutrition, Agricultural University, \\ De Dreijen 3, 6703 BC Wageningen, Netherlands
}

Received 17 January 1983; accepted 3 June 1983

Key-words: plant analysis, nitrate, potentiometry, spectrophotometry

\section{Summary}

The determination of nitrate in plant extracts was tested by three different methods. The methods based on nitration of $\mathrm{O}^{\prime}$-xylenol and dialysis of plant extracts and reduction of $\mathrm{NO}_{3}^{-}$to $\mathrm{NO}_{2}^{-}$by a Cu-Cd reductor were equally satisfactory. No influence of the extraction ratio was found. Extraction of plant material with water or electrolyte solution gave comparable results.

Direct potentiometry gave too high results at lower $\mathrm{NO}_{3}^{-}$levels. This phenomenon depends on the nature of plant material analysed and is apparently caused by organic anions. For spinach the electrode can be used when the nitrate content is about $300 \mathrm{mmol} \mathrm{NO}_{3}^{-} \mathrm{kg}^{-1}$ dry matter or higher.

\section{Introduction}

The importance of the $\mathrm{NO}_{3}^{-}$content in plants used for food consumption has been recognized for a long time. Nitrate ions as such are non-toxic, but under certain conditions they can be reduced to nitrites which, in turn, can react with haemoglobin and disturb the oxygen fixation (Simon, 1966). Furthermore, nitrite can react with some amides and amino acids present in the gastric system and form carcinogenic nitrosamines (Quinche \& Dvorak, 1980).

Several methods have been used for the determination of free nitrates in plant material. The methods based on the nitration of some aromatic compounds suffer from the disadvantage that nitration takes place in rather concentrated sulphuric acid, which causes carbonisation of the organic material present. Separation of the nitro compound formed is therefore necessary. The method proposed by Sørensen (1956), in which the nitro-xylenol formed is distilled off, has been used widely in spite of the lengthy procedure involved. Potentiometric methods with ion-selective electrodes (Paul \& Carlson, 1968; Baker \& Smith, 1969) are expeditive and simple. However, a number of inorganic anions are said to interfere. Especially chlorides may interfere but this can easily be suppressed by the addition of silver ions. To our knowledge, little is known about the influence of organic anions. 
Another useful procedure is the reduction of nitrate to nitrite, followed by the very specific determination of nitrite. Here the reduction step is rather critical; furthermore, the colour of the plant extracts may interfere in the colorimetric measurement and should first be removed.

In the following, we investigate the usefulness of the three methods mentioned above.

\section{Experimental}

Sample preparation

Dried $\left(70{ }^{\circ} \mathrm{C}\right.$ ) plant material, 0.250 to $0.500 \mathrm{~g}$, is extracted $(30$ minutes $)$ with $25 \mathrm{ml}$ of water. After filtration, aliquots are used for nitrate analysis, either potentiometrically or by means of an automated colorimetric procedure. For the nitrate determination by means of $\mathrm{O}^{\prime}$-xylenol, 0.500 to $3.000 \mathrm{~g}$ of dried plant material is extracted (30 minutes) with a solution of $0.16 \mathrm{~mol} \mathrm{l}^{-1} \mathrm{CuSO}_{4}$ and $0.024 \mathrm{~mol} \mathrm{l}^{-1} \mathrm{Ag}_{2} \mathrm{SO}_{4}$ (Sørensen, 1956).

Analytical methods

\section{Automatic spectrophotometric determination}

For the separation of coloured organic compounds and colloids which may be present, the plant extract is first subjected to dialysis. Ionized components from the extract are taken in the understream of $\mathrm{NH}_{4} \mathrm{Cl}$. Next, $\mathrm{NO}_{3}^{-}$ions are reduced on a $\mathrm{Cu}$ $\mathrm{Cd}$ reduction column and the formed $\mathrm{NO}_{2}^{-}$is converted into red coloured $\alpha$-naphtylamine-para-diazo-benzene-parasulphonic acid. The flow diagram used is given in Fig. 1.

\section{Reagents}

- Standard solution of $3000 \mathrm{mg} \mathrm{l}^{-1} \mathrm{NO}_{3}^{-}: 4.8924 \mathrm{~g} \mathrm{l}^{-1} \mathrm{KNO}_{3}$.

- Working standard solutions: pipette 0-2-4-6-8-10 $\mathrm{ml}$ of the standard solution into $100-\mathrm{ml}$ volumetric flasks and dilute to $100 \mathrm{ml}$ with demineralized water. The $\mathrm{NO}_{3}^{-}$concentrations in these standards are: 0-60-120-180-240-300 $\mathrm{mg} \mathrm{l}^{-1} \mathrm{NO}_{3}^{-}$.

- Ammonium chloride solution: $10 \mathrm{~g} \mathrm{l}^{-1} \mathrm{NH}_{4} \mathrm{Cl}$. Add $1 \mathrm{ml}$ Bry-35 and mix.

- Colour reagent: in a volumetric flask of 2 litres containing already 1 litre of demineralized water dissolve $20 \mathrm{~g}$ sulphanilamide, $200 \mathrm{ml}$ concentrated $\mathrm{H}_{3} \mathrm{PO}_{4}$, and 1 g N-1-naphtylethylenediamine. Fill up to the mark with demineralized water. Add $1 \mathrm{ml}$ Bry-35 and mix.

- $\mathrm{Cu}-\mathrm{Cd}$ reductor: $\mathrm{Cd}$ powder (40-60 mesh) is cleaned once with 1 mol $1^{-1} \mathrm{HCl}$ solution until white, then with water to remove acid. $\mathrm{Next}, 20 \mathrm{~g} \mathrm{l}^{-1} \mathrm{CuSO}_{4} \cdot 5 \mathrm{H}_{2} \mathrm{O}$ solution is added. When the colloidal copper appears and flocculates, decant and wash with water until clear. 


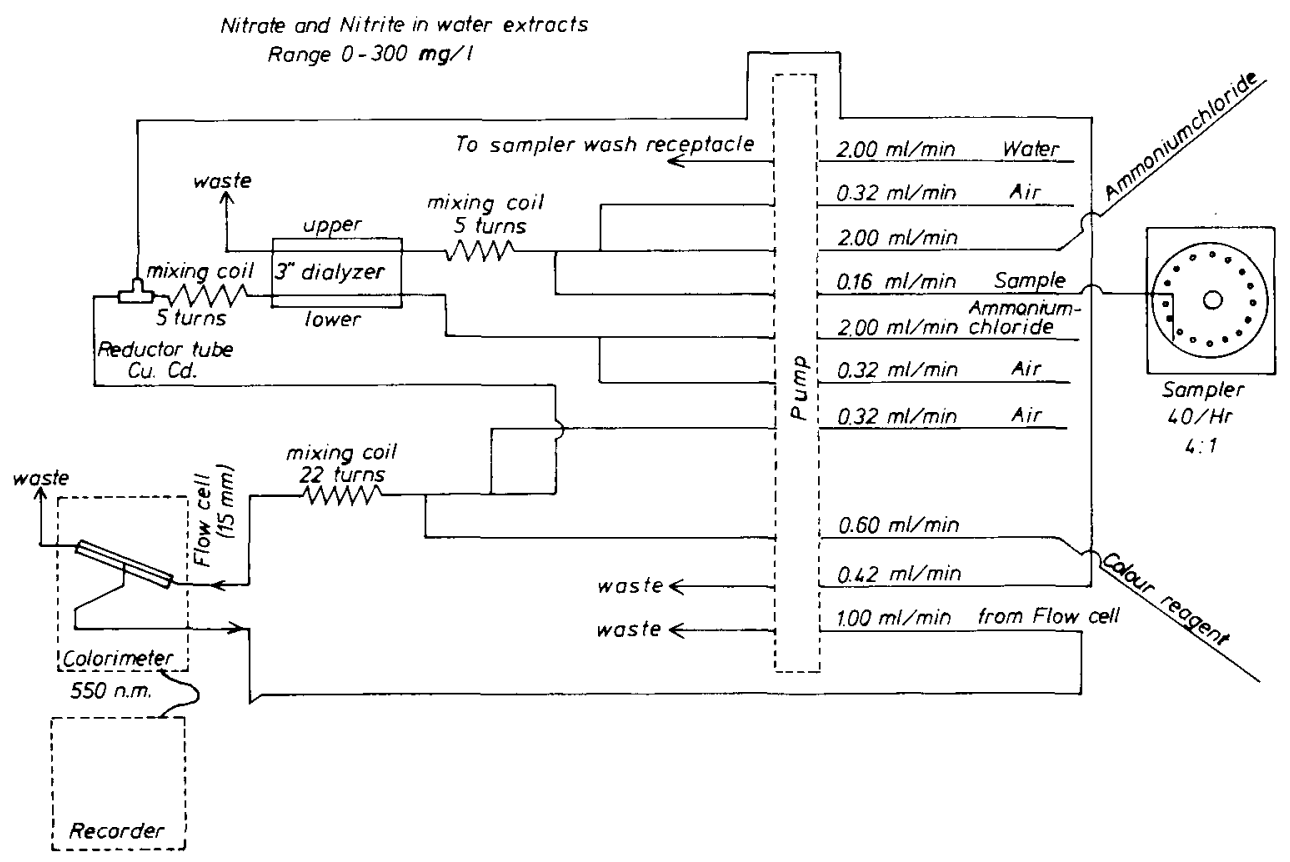

Fig. 1. Flow diagram of the automatic spectrophotometric determination of nitrate.

Spectrophotometric determination by means of nitration of $O^{\prime}$-xylenol

The plant material is extracted with a mixture of $\mathrm{Ag}_{2} \mathrm{SO}_{4}$ and $\mathrm{CuSO}_{4}$ to prevent interference to the extract by chlorides, oxalates, and tannines (Sørensen, 1956). Next, $\mathrm{O}^{\prime}$-xylenol which has been nitrated in a sulphuric acid medium, is added. To prevent condensation in the still, this nitroxylenol is distilled in an alcoholic atmosphere and dissolved in $\mathrm{NaOH}$, yielding a colour.

\section{Reagents}

- Extraction solution: $7.5 \mathrm{~g} \mathrm{l}^{-1} \mathrm{Ag}_{2} \mathrm{SO}_{4}+40 \mathrm{~g} \mathrm{l}^{-1} \mathrm{CuSO}_{4} \cdot 5 \mathrm{H}_{2} \mathrm{O}$.

- Sodium hydroxide $0.4 \mathrm{~mol} \mathrm{l}^{-1}: 16 \mathrm{~g} \mathrm{l}^{-1} \mathrm{NaOH}$.

- $\mathrm{O}^{\prime}$-xylenol: $25 \mathrm{~g}$ 3,4-dimethylphenol per litre $\mathrm{NaOH} 0.2 \mathrm{~mol} \mathrm{l}^{-1}$.

- Sulphuric acid $\left(720 \mathrm{ml} \mathrm{l}^{-1}\right.$ ): add $720 \mathrm{ml} \mathrm{H}_{2} \mathrm{SO}_{4}$ (density 1.84 ) to $280 \mathrm{ml}$ of demineralized water and cool.

- Ethanol $96 \%$.

- Standard solution $200 \mathrm{mg} \mathrm{l}^{-1} \mathrm{NO}_{3}^{-}: 0.326 \mathrm{~g} \mathrm{KNO}_{3}$ per litre demineralized water. Dilute to concentrations of $0-40-80-120-200 \mathrm{mg} \mathrm{l}^{-1} \mathrm{NO}_{\overline{3}}$.

\section{Procedure}

Pipette $5.0 \mathrm{ml}$ of the standard solution or plant extract containing less than $0.9 \mathrm{mg}$ of 
$\mathrm{NO}_{3}^{-}$, into ground glass-stoppered 100-ml Erlenmeyer conical flasks. Fill up to $5 \mathrm{ml}$ with extraction solution and add, successively, $2 \mathrm{ml} \mathrm{O}^{\prime}$-xylenol and $20 \mathrm{ml}$ sulphuric acid $\left(720 \mathrm{ml} \mathrm{l}^{-1}\right)$. Stopper immediately, swirl, and leave for 30 minutes. Then add 50 $\mathrm{ml}$ demineralized water to stop the nitration.

Pipette an aliquot of $25.0 \mathrm{ml}$ of the nitrated solution into a distillation apparatus (Markham still). Add $5 \mathrm{ml}$ ethanol and distill for 1.5 minutes, then add again $5 \mathrm{ml}$ ethanol. The distillate is collected in a $25 \mathrm{ml}$ volumetric flask containing $2.5 \mathrm{ml}$ $\mathrm{NaOH} 0.4 \mathrm{~mol} \mathrm{l}^{-1}$. Proceed the distillation until the volumetric flask is nearly filled. Fill up to the mark with ethanol and mix.

Measure at $430 \mathrm{~nm}(1 \mathrm{~cm}$ cuvette) against water.

\section{Direct potentiometry}

The $\mathrm{NO}_{3}^{-}$activity in water extracts is determined by a nitrate-specific electrode. The membrane of these electrodes contains as active substance mostly $\mathrm{Ni}^{2+}$-orthophenantroline in $\mathrm{NO}_{3}$ form, either dissolved in a hydrophobic organic solvent or inbedded in plastic. According to the manufacturer, the membrane material can withstand a pH range from 2-12. Both types have been used in this study.

For the concentration measurements an ionic strength buffer must be added. As such, 0.2 or $0.013 \mathrm{~mol} \mathrm{l}^{-1} \mathrm{Al}_{2}\left(\mathrm{SO}_{4}\right)_{3}$ solution or $0.2 \mathrm{~mol} \mathrm{l}^{-1} \mathrm{Na}_{2} \mathrm{HPO}_{4}$ solution, together with an addition of Dowex 50-X8 (20-50 mesh) saturated with aluminium, is used. In both systems aluminium buffers the $\mathrm{pH}$ of the measuring solution to 3.7. A constant $\mathrm{pH}$ value is important because of possible interference by other anionic species. At that $\mathrm{pH}$ the dissociation of weak acids (hydrogen carbonate) is completely suppressed. For other anions the degree of protonization is kept constant. Furthermore, it has been suggested that through complex formation with $\mathrm{Al}^{3+}$ some interference of mainly organic anions can be suppressed (Paul \& Carlson, 1960).

\section{Reagents}

- Standard solution of $3000 \mathrm{mg} \mathrm{l}^{-1} \mathrm{NO}_{3}^{-}: 4.8924 \mathrm{~g} \mathrm{l}^{-1} \mathrm{KNO}_{3}$. Dilute to concentrations of 1-3-10-30-100-300 $\mathrm{mg} \mathrm{l}^{-1} \mathrm{NO}_{\overline{3}}^{-}$.

- Buffer solutions:

aluminium sulphate $0.2 \mathrm{~mol} \mathrm{l}^{-1}: 66.6 \mathrm{~g} \mathrm{l}^{-1} \mathrm{Al}_{2}\left(\mathrm{SO}_{4}\right)_{3} \cdot 18 \mathrm{H}_{2} \mathrm{O}$.

aluminium sulphate $0.013 \mathrm{~mol} \mathrm{l}^{-1}: 4.44 \mathrm{~g} \mathrm{l}^{-1} \mathrm{Al}_{2}\left(\mathrm{SO}_{4}\right)_{3} \cdot 18 \mathrm{H}_{2} \mathrm{O}$.

potassium dihydrogen phosphate $0.2 \mathrm{~mol} \mathrm{l}^{-1}: 27.2 \mathrm{~g} \mathrm{l}^{-1} \mathrm{KH}_{2} \mathrm{PO}_{4}$.

- Aluminium resin: mix a slurry of hydrogen-saturated Dowex 50-X8 (20-50 mesh) resin with an amount of $\mathrm{Al}_{2}\left(\mathrm{SO}_{4}\right)_{3}$ exceeding the absorption capacity of the resin by about $25 \%$. Let standing overnight. Filter and remove salts by washing. Remove most of the capillary water and store in a well-stoppered bottle.

\section{Equipment}

$\mathrm{pH} / \mathrm{mV}$ meter: Radiometer pHM-64.

Selective electrode Orion (model 93-07).

Selective electrode Activion (model 00315 013).

$\mathrm{Hg} / \mathrm{Hg}_{2} \mathrm{SO}_{4} / \mathrm{K}_{2} \mathrm{SO}_{4}$ reference electrode. 


\section{Procedure}

Add $5.0 \mathrm{ml}$ buffer solution, with or without aluminium resin, to $5.0 \mathrm{ml}$ sample and standard solutions. All potentiometric measurements must be performed at constant temperature.

\section{Results}

\section{Automatic spectrophotometric determination}

Besides nitrates water extracts of plant material contain chlorides, sulphates, phosphates, hydrogen carbonates, and a number of soluble organic compounds. For concentrations up to $1 \mathrm{mmol} \mathrm{l}^{-1}$ (corresponding to about $2 \mathrm{~mol}$ of organic anion per $\mathrm{kg}$ dry matter) no influence has been found of the following anions: succinate, ascorbate, citrate, malonate, oxalate, and fumarate. High concentrations of organic anions can influence the results negatively. For instance, experiments with $0.5 \mathrm{~mol}$ $1^{-1}$ acetic acid as measuring medium yielded a $20 \%$ signal depression. No interference has been found from phosphate or sulphate up to $6.5 \mathrm{mmol}^{-1}$.

Since primary amines are known to interfere with spectrophotometric determination, the influence of glutamine, asparagine, and urea was tested and found to be negligibly small for concentrations up to $100 \mathrm{mg} \mathrm{l}^{-1}$.

As representative of the compounds of the type R-SH, cysteine also was tested. The results in Table 1 indicate that the reductor was poisoned. It is likely that other sulphide-containing organic compounds and sulphide itself have the same influence. The concentrations tested were rather high, corresponding to 320 en 640 mmol cysteine $\mathrm{kg}^{-1}$ dry matter.

Because of this behaviour, it is recommended that pure standard $\mathrm{NO}_{3}^{-}$solutions are analysed rather frequently for proper working of the reductor.

Spectrophotometric determination by means of nitration of $O^{\prime}$-xylenol

Interferences with this determination method were studied already by Sørensen (1956). This method is regarded as a reference method and we used it with only minor modifications.

Table 1. Relative influence of cysteine on the automatic nitrate determination.

\begin{tabular}{rllccc}
\hline $\mathrm{NO}_{3}\left(\mathrm{mg} \mathrm{l}^{-1}\right)$ & $\mathrm{NO}_{3}^{-*}$ & $\begin{array}{l}\mathrm{NO}_{3}^{-}+3.1 \mathrm{mmol} \mathrm{l}^{-1} \\
\text { cysteine }\end{array}$ & $\mathrm{NO}_{3}^{-}$ & $\begin{array}{l}\mathrm{NO}_{3}+6.2 \mathrm{mmol} \mathrm{I}^{-1} \\
\text { cysteine }\end{array}$ & $\mathrm{NO}_{3}$ \\
0 & 100 & 100 & 100 & 100 & 100 \\
60 & 100 & 88 & 50 & 29 & 29 \\
120 & 100 & 85 & 54 & 24 & 32 \\
180 & 100 & 76 & 56 & 21 & 39 \\
240 & 100 & 63 & 58 & 21 & 41 \\
300 & 100 & 53 & 61 & 19 & 49 \\
\hline
\end{tabular}

* The measurements were performed in the sequence as presented in the table. 
Table 2. Selectivity coefficients of some organic anions with the $\mathrm{NO}_{3}^{-}$-selective electrode (measured at $\mathrm{pH} 3.5$ ).

\begin{tabular}{ll}
\hline Anion & Selectivity coefficient \\
Malate & 0.03 \\
Succinate & 0.009 \\
Acetate & 0.006 \\
Citrate & 0.015 \\
Fumarate & 0.005 \\
Malonate & 0.09 \\
Oxalate & 0.02 \\
\hline
\end{tabular}

\section{Direct potentiometry}

No difference was observed in the behaviour of the two types of nitrate-selective electrodes used. Therefore, no further distinction has been made in the reported results. The selectivity of the $\mathrm{NO}_{3}^{-}$electrode with respect to most organic anions has, to the best of our knowledge, not yet been studied. Since organic ions may be present in rather high concentrations in water extracts of plant material, the selectivity coefficients of some of these anions were determined following the method of Reichnitz (Koryta, 1975). The solutions with different concentrations of organic anions and nitrate were brought to $\mathrm{pH} 3.5$ (by addition of $\mathrm{NaOH}$ ), which is about the value reached by buffering plant extracts with aluminium ions. This means that the found selectivity coefficients are 'composite' coefficients which include the differences in protonization of the respective anions. Therefore, it should be realized that increasing dissociation at higher $\mathrm{pH}$ will increase the interference. The selectivity coefficients are tabulated in Table 2 and the protonization constants of the tested organic acids in Table 3.

\section{Comparison of the spectrophotometric methods}

A number of plant samples were analysed by both the $\mathrm{O}^{\prime}$-xylenol and the automatic spectrophotometric method. The results were essentially the same, regardless of the nitrate content in the plant material and the kind of plant material (Table 4). Furthermore, it appears that the type of extracting solution is of no importance,

Table 3. pK values of some organic acids. (From Sillen \& Martell, 1964.)

\begin{tabular}{llll}
\hline Organic acid & $\mathrm{pK} 1$ & $\mathrm{pK} 2$ & $\mathrm{pK} 3$ \\
& & & \\
Malic acid & 3.47 & 5.10 & - \\
Succinic acid & 4.22 & 5.64 & - \\
Acetic acid & 4.76 & - & - \\
Citric acid & 3.14 & 4.77 & 6.39 \\
Fumaric acid & 3.02 & 4.39 & - \\
Malonic acid & 2.69 & 5.68 & - \\
Oxalic acid & 1.25 & 4.25 & - \\
\hline
\end{tabular}


Table 4. Nitrate concentrations in plant samples as determined by two different spectrophotometric methods.

\begin{tabular}{lcc}
\hline Plant material & \multicolumn{2}{c}{$\mathrm{NO}_{3}^{-}$(mmol kg-1 dry material) } \\
\cline { 2 - 3 } & $\begin{array}{l}\text { automatic spectrophoto- } \\
\text { metric method }\end{array}$ & $\mathrm{O}^{\prime}$-xylenol method \\
Grass 1 & 12 & \\
Grass 2 & 14 & 16 \\
Grass 3 & 14 & 14 \\
Grass 4 & 380 & 13 \\
Spinach 1 & 10 & 377 \\
Spinach 2 & 35 & 10 \\
Spinach 3 & 70 & 32 \\
Spinach 4 & 535 & 85 \\
Spinach 5 & 770 & 545 \\
Spinach 6 & 413 & 775 \\
Spinach 7 & 280 & 523 \\
Amaryllus, leaf & 60 & 285 \\
Maize & 35 & 46 \\
Sugar-beet, leaf 1 & 17 & 31 \\
Sugar-beet, leaf 2 & 17 & 19 \\
Cucumber 1 & 177 & 20 \\
Cucumber 2 & 197 & 191 \\
Lucerne & 10 & 212 \\
Peas, grain & 0 & 10 \\
Cacao, leaf & 5 & 0 \\
Oil palm, leaf & 0 & 5 \\
Radish, leaf & 11 & 0 \\
Chrysanthenum, leaf & 1085 & 10 \\
Lettuce & 1525 & 1075 \\
l. & & 1505 \\
\hline
\end{tabular}

because they differ for the two methods. For the $\mathrm{O}^{\prime}$-xylenol method the extraction ratio was varied depending on the nitrate content in the plant, while for the automatic method the ratio of gram of dry matter per ml water was varied from 1:50 to 1:200 for each sample. No influence of the extracting ratio could be detected.

Based on these results the $\mathrm{O}^{\prime}$-xylenol method has been omitted in the following evaluations.

Comparison of the potentiometric methods with the automatic spectrophotometric method

The electivity coefficients in Table 2 suggest that positive interference with the potentiometric methods can be expected when the nitrate content is low or when the concentration of organic anions in the extract is high. This means that in comparing the methods the type of plant may be important. For this reason field-grown spinach was chosen as a test plant. In this way, we obtained material with variable nitrate content and, the same time, high concentrations of water soluble organic anions, mainly oxalates. For a 1:50 extraction ratio, the oxalate concentration in these extracts was found to be about $5 \mathrm{mmol}^{-1}$. 


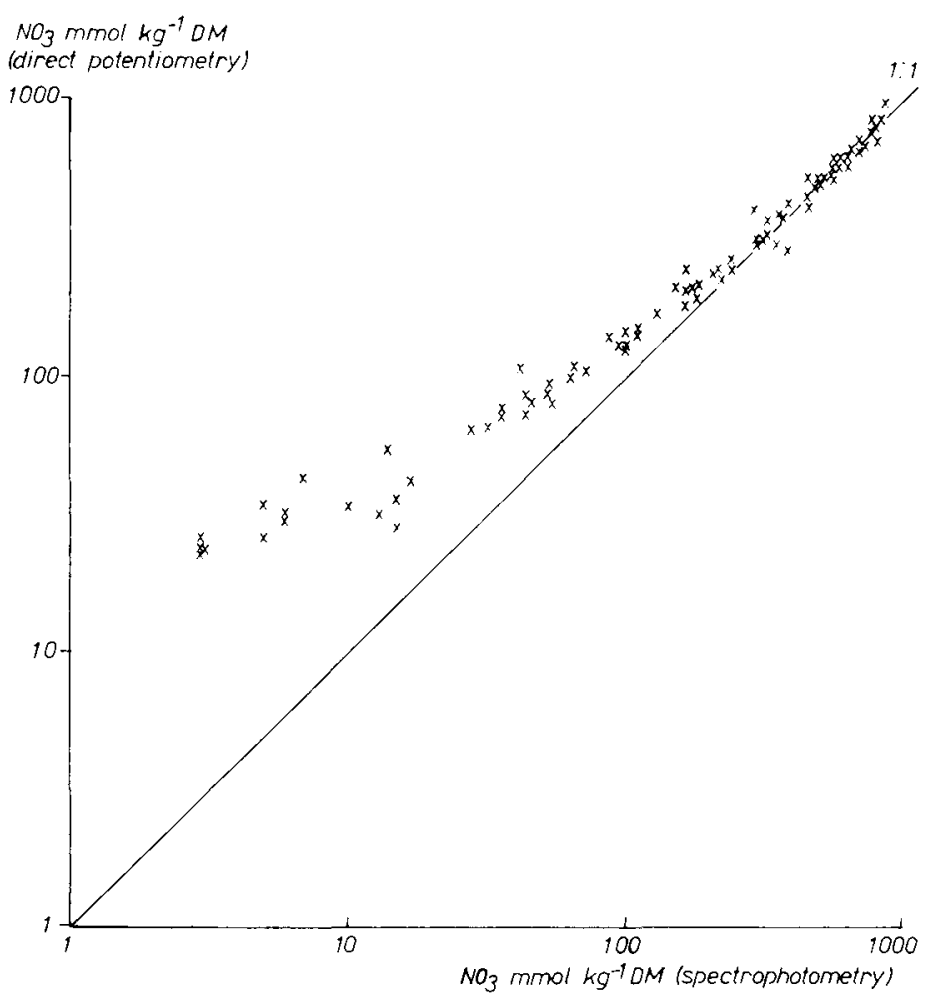

Fig. 2. Comparison of potentiometric and spectrophotometric determination of nitrate in extracts of dry plant material.

These plant samples were extracted and the nitrate contents were determined spectrophotometrically and by direct potentiometry, using $\mathrm{KH}_{2} \mathrm{PO}_{4}$ as an ionic buffer with aluminium-saturated resin.

As expected, the values obtained by direct potentiometry at lower nitrate contents show a positive deviation (Fig. 2). At nitrate concentrations higher than about 250 mmol $\mathrm{NO}_{3}^{-} \mathrm{kg}^{-1}$ dry spinach material, both methods can be used. Earlier investigations by $\mathrm{N}$. Vertregt (pers. comm.) showed that for Graminarae both methods could be used at concentrations as low as $30 \mathrm{mmol} \mathrm{NO}_{3}^{-} \mathrm{kg}^{-1}$ dry material. These results indicate that the type of plant material should be taken into account when chosing direct potentiometry as the analytical method.

It has been suggested (Paul \& Carlson, 1968; Baker \& Smith, 1969) that the aluminium ions introduced in the direct potentiometric measurements not only buffer the $\mathrm{pH}$ and eventually the ionic strength, but are also able to form complexes with organic anions and thereby suppress the possible interferences. To test this behaviour extracts of plant material were buffered with $\mathrm{KH}_{2} \mathrm{PO}_{4}$ plus aluminium resin or with two different concentrations of $\mathrm{Al}_{2}\left(\mathrm{SO}_{4}\right)_{3}$. Again, the same extracts were also 


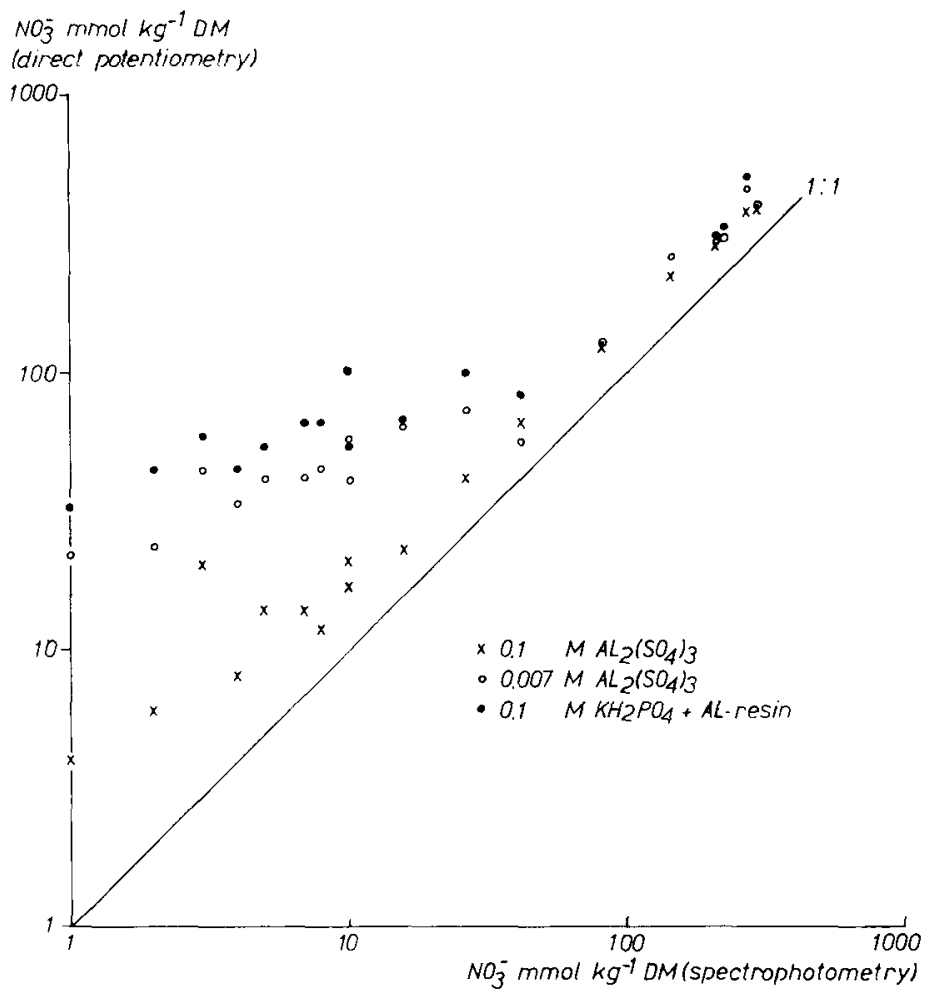

Fig. 3. Potentiometric determination with different buffers of nitrate in extracts of dry plant material compared with a spectrophotometric determination.

analysed spectrophotometrically for nitrate. The results in Fig. 3 demonstrate that high concentrations of $\mathrm{Al}_{2}\left(\mathrm{SO}_{4}\right)_{3}$ suppress the interference better than either of the other buffers. However, the positive interference remained.

As a result of these investigations, the automatic spectrophotometric method has been chosen for routine purposes at our laboratory.

\section{Acknowledgements}

We thank Dr T. Breimer to put at our disposal samples of spinach from his field experiments, E. Nab, Ch. Koot, H. Lenting and miss W. van Vark for carrying out part of the analytical work.

Furthermore we thank Ir J. Ch. van Schouwenburg for the critical reading of the manuscript. 


\section{NOVOZAMSKY ET AL.}

\section{References}

Baker, A. S. \& R. Smith, 1969. Extracting solution for potentiometric determination of nitrate in plant tissue. J. Agric. Food Chem. 17: 1284-1287.

Koryta, J., 1975. Ion-selective electrodes. Cambridge University Press, pp. 64-67.

Paul, J. L. \& R. M. Carlson, 1968. Nitrate determination in plant extracts by the nitrate electrode. J. Agric. Food Chem. 16: 766-768.

Quinche, J. P. \& V. Dvorak, 1980. Le dosage des nitrates dans les légumes, les plantes condimentaires et les terres par ionométrie et par chromatographie gaz-liquide. Revue Suisse Vitic. Arboric. Hortic. 12: 7-20.

Sillen, L. G. \& A. Martell, 1964. Stability constants of metal-ion complexes. The Chemical Society, Burlington House, London.

Simon, C., 1966. Nitrate poisoning from spinach. Lancet 16-4: 872.

Sørensen, C., 1956. The xylenol method and determination of nitrate in beets. Physiologia Plantarum 9 : 304-320. 